\title{
MAKNA DAN NILAI AJARAN BUDI PEKERTI MANTRA DALAM TRADISI MAGUTI
}

\author{
Kodrat Eko Putro Setiawan \\ Universitas PGRI Madiun \\ Jl. Setiabudi No. 85, Kanigoro, Kartoharjo, Kota Madiun, Jawa Timur 63118 \\ Email: kodratekoputrosetiawan08@gmail.com
}

\begin{abstract}
Abstrak
Mantra merupakan ucapan yang memiliki kekuatan gaib. Penelitian ini bertujuan mendeskripsikan makna mantra dan nilai ajaran budi pekerti yang terkandung dalam tradisi Maguti. Metode dalam penelitian ini ialah deskriptif kualitatif. Teknik pengumpulan data meliputi observasi partisipatif, wawancara, studi dokumen dan studi kepustakaan. Hasil penelitian ini antara lain: makna mantra yang terkandung dalam tradisi Maguti ialah siraman pertama/tanggal satu cahaya wajah anak belum begitu bercahaya, sampai akhirnya tanggal limabelas bercahaya seperti bulan purnama; memperingati berasalnya dari bapak (putih) ibu (merah) atau air dan ari-ari sukma yang menjaga jiwa dan raganya anak yang dipaguti; memperingati saudara tua, orang yang melahirkan pertama itu mengeluarkan air dan daging yang menempel pada pusar; memperingati nabi dan rasul, istri dan anaknya, serta sahabatnya Usman, Umar, Syaidina, Ngali; memperingati ibu Dewi Fatimah yang menjadi contoh semua perempuan; memperingati leluhur perempuan laki-laki yang bertempat di kiblat empat lima pancer; memperingati para leluhur laki-laki perempuan, tua-muda, jauh-dekat dimintai doa restu yang baik; memperingati nabi Sulaiman yang menguasai dedaunan, kayu, air, ayam/semua hewan yang disembelih untuk perlengkapan; semua perlengkapan untuk memperingati tujuh hari. Nilai ajaran budi pekerti yang terkandung adalah tumbuhnya disiplin diri; mampu berpikir positif; menumbuhkan cinta dan kasih sayang, rasa saling menghormati, memiliki tata krama dan sopan santun; menaati ajaran agama dan mengembangkan sikap toleransi; memiliki rasa tanggung jawab; rasa bakti kepada orang tua; mengembangkan etos kerja dan belajar.
\end{abstract}

Kata Kunci : Maguti, Mantra, Makna, Nilai, Budi Pekerti.

\section{PENDAHULUAN}

Bangsa Indonesia mempunyai suku bangsa yang beragam. Hal itu melahirkan berbagai kebudayaan yang terdapat di dalamnya. Keanekaragaman suku yang dipunyai bangsa Indonesia juga menjadi aset yang harus dijaga keberadaannya. Salah satu suku yang menjadi aset Indonesia adalah suku Jawa. Herusatoto (2001:1) menjelaskan bahwa suku Jawa adalah suku terbesar yang ada di Indonesia, keberadaan suku ini cukup mewarnai dalam beberapa hal, antara lain dalam bidang tradisi, budaya, bahasa, etika dan estetika bahkan filsafatnya. Budaya yang dimiliki suku Jawa dikenal cukup halus dan penuh makna dengan simbol-simbol yang tidak mudah untuk dipahami secara kasatmata. Memang tidak mudah memahami makna yang sebenarnya dari kegiatan yang dilakukan orangorang Jawa.

Masyarakat Jawa mempunyai tradisi adat-istiadat secara turun menurun. Perkembangan zaman menyebabkan kedudukan budaya dalam pola masyarakat bersifat dinamis. Namun demikian, hal tersebut tidak berpengaruh dalam eksistensi nilai-nilai budaya. Nilai budaya yang di maksudkan adalah makna yang terkandung dalam budaya yang bermanfaat bagi tatanan kehidupan. Makna tersebut terbentuk sesuai dengan kebutuhan masyarakat setempat hingga akhirnya membentuk tradisi (Setiawan, 2019:82).

Tradisi merupakan adat kebiasaan yang diturunkan dari nenek moyang yang masih dilaksanakan dalam masyarakat. Dalam pengertian yang sederhana, tradisi ialah sesuatu yang dilakukan sejak lama dan menjadi bagian dari kehidupan masyarakat. Tradisi yang ada dalam suatu masyarakat sudah melekat erat. Hal tersebut menjadikan masyarakat menjunjung tinggi nilai luhur dalam tradisi tersebut. Tradisi berasal dari bahasa Latin : traditio, artinya diteruskan, menurut artian bahasa adalah sesuatu kebiasaan yang berkembang di masyarakat baik, yang menjadi adat kebiasaan, atau yang diasimilasikan dengan ritual adat atau agama (Widodo, 2014:266).

Keberadaan tradisi Maguti tidak lepas dari pola pikir masyarakat yang memahami bahwa Maguti menjadi bagian dari kebudayaan Jawa, yang merupakan kristalisasi pemikiran- 
pemikiran lama, yaitu manusia Jawa berkeyakinan kepada sang Maha Pencipta, penyebab dari segala kehidupan; manusia Jawa berkeyakinan bahwa manusia adalah bagian dari kodrat alam semesta (makro kosmos), manusia dengan alam saling mempengaruhi. Tetapi manusia harus sanggup melawan kodrat alam sesuai dengan kehendak cita-cita, agar dapat hidup selamat baik di dunia maupun diakhirat. Hasil dari perjuangan perlawanan terhadap kodrat alam tersebut berasal dari kemajuan dan kreativitas kebudayaan, sehingga terjalin keselarasan dan kebersamaan yang didasarkan pada saling hormat, saling tenggang rasa, saling mawas diri; manusia Jawa rindu akan kondisi "tata tentrem kerta raharja" yaitu suatu keadaan yang damai, sejahtera, aman, sentosa berdasar pada "kautamaning ngaurip" (keutamaan hidup), sehingga manusia Jawa berkewajiban untuk "memayu hayuning raga, sesama, bangsa, dan bawana" (Sutardjo, 2012:15).

Tradisi Maguti tidak dapat dilepaskan dari konteks kebudayaan karena Maguti merupakan bagian dari tujuh unsur kebudayaan yang disebut cultural universal yang terdiri dari bahasa; sistem pengetahuan; organisasi sosial; sistem peralatan hidup dan teknologi; sistem mata pencaharian; sistem religi; dan kesenian. (Koentjaraningrat, 1984:203-204).

Nilai-nilai luhur yang mengendap sebagai kekayaan budaya setempat tersusun dalam simbolisme tradisi Maguti. Nilai-nilai yang membangun konsep tradisi Maguti ialah kecerdasan dalam memberikan makna spiritual, imajinasi, kepekaan, nilai sopan santun, dan keselarasan. Oleh sebab itu, budaya kolektif seperti halnya tradisi Maguti, simbol menjadi suatu relasi dari struktur-struktur yang berisi pesan budaya. Pesan tersebut adalah pendidikan nilai-nilai yang harus dimaknai melalui wujud berbagai teks dan aspek sosial sebagai konteksnya. Ronald (1993:2) menjelaskan bahwa prinsip hidup dalam tradisi yang cenderung mistis, lebih mengutamakan nilai harmoni dengan kosmonya, pengetahuan kosmologi, dan sistem kepercayaan sinkretisme (kejawen). Pemberian makna simbol akan tepat jika memahami alam pikiran di mana simbol itu dilahirkan.

Modernisasi dapat berdampak pada perubahan tradisi yang ada dalam masyarakat Jawa. Meskipun demikian, tidak semua tradisi mengalami perubahan dan justru dapat mempertahankan keberadaannya. Oleh sebab itu, tradisi yang dimiliki masyarakat Jawa yang sangat beragam menjadi sebuah kebanggaan sekaligus tantangan tersendiri untuk mempertahankan (eksistensinya) dan mewariskannya kepada anak dan cucu. Tradisi yang masih terjaga keasliannya sampai saat ini satu di antaranya adalah Maguti.

Maguti merupakan salah satu tradisi yang masih ada di Desa Jagir, Kecamatan Sine, Kabupaten Ngawi, Jawa Timur. Penelitian ini bertujuan mengkaji tradisi Maguti yang masih dilaksanakan masyarakat Desa Jagir, dengan pokok kajian yaitu makna dan nilai ajaran budi pekerti mantra dalam tradisi Maguti. Penelitian ini bertujuan memberikan informasi dengan mendeskripsikan makna mantra dalam tradisi Maguti dan mendeskripsikan nilai ajaran budi pekerti yang terkandung dalam mantra pada pelaksanaan tradisi Maguti.

\section{METODE PENELITIAN}

Metode yang digunakan dalam penelitian ini adalah deskriptif kualitatif. Peneliti melakukan kajian kepustakaan dan studi di lapangan untuk pengecekan data dan kelengkapan fakta. Singaribun (1982:45) menjelaskan bahwa kajian kepustakaan (Library Research) bertujuan untuk menggali teori-teori dasar dan konsep yang telah disampaikan para pakar terdahulu, mengikuti perkembangan penelitian dalam bidang yang akan dikaji, memperoleh orientasi yang lebih luas mengenai topik yang dipilih, memanfaatkan data sekunder.

Studi lapangan yang dilakukan peneliti adalah mendatangi kegiatan pelaksanaan upacara tradisi Maguti yang ada di desa Jagir, Kecamatan Sine, Kebupaten Ngawi. Peneliti juga melakukan wawancara dengan beberapa sesepuh desa yang terlibat langsung dengan pelaksanaan upacara tradisi tersebut. Hal tersebut digunakan peneliti untuk mendapatkan penjelasan makna-makna yang ada dalam pelaksanaan upacara tradisi Maguti secara langsung.

Teknik pengumpulan data meliputi observasi partisipatif, wawancara, studi dokumen dan studi kepustakaan. Observasi partisipatif, peneliti terlibat dalam kegiatan sehari-hari orangorang yang sedang diamati. Selain melakukan pengamatan, peneliti juga ikut berpartisipasi dalam menyiapkan perlengkapan dan pelaksanaan tradisi Maguti yang dilakukan oleh informan. Hal tersebut dilakukan supaya data yang didapatkan lebih lengkap, hingga peneliti 
mengetahui makna dari setiap perilaku yang terlihat dalam tradisi Maguti.

Wawancara yang dilakukan adalah indepth interview (wawancara mendalam), dengan melakukan tanya jawab dengan informan secara bebas dengan tujuan menemukan permasalahan secara lebih terbuka. Artinya, informan yang diwawancarai dimintai pendapat dan idenya. Peneliti mencatat dan memperhatikan secara teliti informasi yang disampaikan informan. Langkahlangkah yang dilakukan antara lain: menentukan orang yang akan diwawancarai, menentukan pokok maslah yang menjadi bahan pembicaraan, mengawali alur wawancara, mengomunikasikan ikhtisar hasil wawancara dan mengakhirnya, menulis hasil wawancara dalam catatan lapangan, dan mengidentifikasi tindak lanjut hasil wawancara tadi.

Studi dokumen dalam penelitian ini merupakan catatan peristiwa yang sudah terjadi. Dokumennya berbentuk tulisan dan gambar. Dokumen berbentuk tulisan berupa catatan harian dan cerita yang berkaitan dengan tradisi Maguti. Sedangkan dokumen berbentuk gambar berupa foto-foto kegiatan tradisi Maguti. Studi dokumen ini menjadi pelengkap dari observasi dan wawancara.

Studi kepustakaan yang dilakukan adalah pengumpulan referensi dari buku, jurnal dan hasil penelitian terdahulu yang berkaitan kajian budaya Jawa. Khususnya dalam konteks perkembangan makna dari tradisi Maguti. Semua itu dilakukan untuk mendapatkan pengertian-pengertian dan konsep-konsep yang dikembangkan dalam penelitian.

\section{HASIL DAN PEMBAHASAN}

Berikut ini akan dideskripsikan dan dijelaskan makna dan nilai ajaran budi pekerti yang terkandung dalam mantra pada pelaksanaan tradisi Maguti:

\section{Data 1}

"Siram kepisan cahyaning bocah koyo tanggal sepisan utawa tanggal siji, siram kepindho cahyaning bocah koyo tanggal loro, siram tanggal ketelu cahyaning bocah koyo tanggal telu, siram kepapat cahyaning bocah koyo tanggal papat, siram kelimo cahyaning bocah koyo tanggal lima, siram keenem cahyaning bocah koyo tanggal enem, siram kepitu cahyaning bocah koyo tanggal pitu, siram kewolu cahyaning bocah koyo tanggal wolu, siram kesongo cahyaning bocah koyo tanggal songo, siram kesepuluh cahyaning bocah koyo tanggal sepuluh, siram kesewelas cahyaning bocah koyo tanggal sewelas, siram kerolas cahyaning bocah koyo tanggal rolas, siram ketelulas cahyaning bocah koyo tanggal telulas, siram ping patbelas cahyaning bocah koyo tanggal patbelas, siram ping limolas cahyaning bocah koyo tanggal limolas".

Arti mantra di atas ialah siraman yang pertama, wajah anak yang dipaguti seperti tanggal satu, siraman kedua wajah anak tersebut seperti tanggal dua, siraman ketiga, wajah anak tersebut seperti tanggal tiga, siraman ke empat wajah anak tersebut seperti tanggal empat, siraman kelima wajah anak tersebut seperti tanggal lima, siraman keenam wajah anak tersebut seperti tanggal enam, siraman ke tujuh wajah anak tersebut seperti tanggal tujuh, siraman kedelapan wajah anak tersebut seperti tanggal delapan, siraman kesembilan wajah anak tersebut seperti tanggal sembilan, siraman kesepuluh wajah anak tersebut seperti tanggal sepuluh, siraman kesebelas wajah anak tersebut seperti tanggal sebelas, siraman keduabelas wajah anak tersebut seperti tanggal duabelas, siraman ketiga belas wajah anak tersebut seperti tanggal tiga belas, siraman keempat belas wajah anak tersebut seperti tanggal empatbelas, siraman kelimabelas wajah anak tersebut seperti tanggal limabelas.

Makna mantra di atas ialah dari siraman pertama/tanggal satu cahaya wajah anak belum begitu bercahaya, sampai akhirnya tanggal limabelas bercahaya seperti bulan purnama. Tanggal limabelas tersebut maksudnya ialah tanggalan Jawa. Nilai ajaran budi pekerti yang terkandung dalam mantra di atas ialah tumbuhnya disiplin diri dan mampu berpikir positif. Disiplin diri yang di maksudkan ialah secara urut prosedur yang ada dalam mantra tersebut dilaksanakan pada prosesi Maguti. Nilai mampu berpikir positif dalam mantra tersebut ialah "wajah anak yang bercahaya" artinya ada aura positif yang muncul ketika memiliki pikiran yang positif pula.

\section{Data 2}

"Mengeti soko bapa biyung utawi kakang kawah adi ari-ari, ninimong kaki among sing momong jiwo ragane sing di paguti ingkang manggon kiblat sekawan enem pancer. Sing tebih tanpa winangenan, celak tansah sesarengan".

Maknanya memperingati berasalnya dari bapak (putih) ibu (merah) atau air dan ari-ari sukma yang menjaga jiwa dan raganya anak yang dipaguti, bertempat di kiblat empat enam pancer, 
maksudnya timur-barat, utara-selatan, atasbawah. Nilai ajaran budi pekerti yang terkandung dalam mantra di atas ialah menumbuhkan cinta dan kasih sayang, rasa saling menghormati, memiliki tata krama dan sopan santun. Nilai-nilai tersebut penting terutama untuk mengingatkan seorang anak yang harus berbakti kepada ibu dan bapak atau orang yang lebih tua.

\section{Data 3}

"Mengeti sedulur tua, kakang kawah adi ari-ari" Maknanya, memperingati saudara tua, orang yang melahirkan pertama itu mengeluarkan air dan daging yang menempel pada pusar. Nilai ajaran budi pekerti yang terkandung dalam mantra tersebut ialah menumbuhkan cinta dan kasih sayang terutama kepada ibu yang telah melahirkan kita. Selain itu juga terdapat nilai ajaran budi pekerti berupa ihsan yakni kebaikan terhadap saudara.

\section{Data 4}

"Kangge mengeti kanjeng Nabi Rosul sak garwa putra sak kabat sekawan Usman, Umar, Syaidina, Ngali"

Maknanya untuk memperingati nabi dan rasul, istri dan anaknya, serta sahabatnya Usman, Umar, Syaidina, Ngali. Hal itu juga berarti bahwa manusia Jawa harus selalu mengingat kanjeng Nabi dan keluarga serta sahabat-sahabatnya sebagai perwujudan dari sikap religius yang dimiliki masyarakat Jawa pada umumnya dan masyarakat Jawa yang memeluk agama Islam khususnya. Nilai ajaran budi pekerti yang terkandung dalam mantra tersebut ialah menaati ajaran agama dan mengembangkan sikap toleransi.

\section{Data 5}

"Kasebat pisang ayu, sedah ayu kangge mengeti mbok Dewi Fatimah sami ingkang minangka dados panutanipun sedaya estri".

Maknanya, disebut pisang ayu sedah ayu yang digunakan untuk memperingati ibu Dewi Fatimah yang menjadi contoh semua perempuan. Pisang ayu artinya pisang raja dua sisir yang ditaruh di atas baskom dan sedah (daun sirih, gambir, tembakau, apu). Hal itu menunjukkan bahwa ibu Dewi Fatimah menjadi tauladan bagi perempuan Jawa sehingga memiliki kepribadian yang baik. Perempuan dalam adat Jawa memiliki kedudukan dan derajat yang tinggi. Peran perempuan dalam masyarakat Jawa dianggap penting, tidak hanya mengasuh dan mendidik anak serta mendampingi suami, namun juga diperkenankan untuk keluar rumah untuk melakukan kegiatan ekonomi. Selain itu, perempuan dalam budaya Jawa adalah sebagai pusat keluarga. Nilai ajaran budi pekerti yang terkandung dalam mantra tersebut ialah mengembangkan sikap toleransi; memiliki rasa tanggung jawab; menumbuhkan cinta dan kasih sayang; memiliki tata krama dan sopan santun.

\section{Data 6}

"Kangge caos dhahar memule ninidayang kakidayang ingkang manggen wonten kiblat sekawan lima pancer bapa angkasa ibu bumi ingkang dilenggahi ingkang kagungan hajat kasuwun berkah pangestunipun ingkang wilujeng ngajeng sak pawingkingipun".

Maknanya, untuk memperingati leluhur perempuan laki-laki yang bertempat di kiblat empat lima pancer. Lima pancer maksudnya timur-barat,utara-selatan, yang ditempati yang dipaguti. Secara pengertian yang mendalam, bahwa kita punya pepundhen (leluhur) yang sudah meninggal dunia, jangan sampai lupa bahwa asal-usul ada di dunia dan bisa hidup di dunia itu awalnya dari siapa sehingga sangat penting untuk mendoakan leluhur karena menjadi suatu bentuk berbakti kepada orang tua dengan cara mengirimkan doa agar para leluluhur bisa masuk surga. Nilai ajaran budi pekerti yang terkandung dalam mantra tersebut ialah rasa bakti kepada orang tua; menumbuhkan cinta dan kasih sayang; memiliki tata krama dan sopan santun.

\section{Data 7}

"Kangge ngintun sedaya leluhuripun jaler estri sepuh anem tebih celak kasuwuni idi pangestunipun ingkang wilujeng".

Maknanya untuk memperingati para leluhur laki-laki perempuan, tua-muda, jauhdekat dimintai doa restu yang baik. Hal itu juga terdapat dalam ungkapan Jawa, aja wani marang para leluhur, jalaran para leluhur iku kagolong bathara. Artinya, harus menghormati terhadap para leluhur, karena mereka termasuk bathara. Makna ungkapan tersebut ialah anjuran untuk menghormati orang tua kita, baik yang masih hidup maupun yang sudah meninggal. Nilai ajaran budi pekerti yang terkandung dalam mantra tersebut ialah menumbuhkan cinta dan kasih sayang; memiliki tata krama dan sopan santun.

\section{Data 8}

"Kangge mengeti kanjeng nabi Sulaiman ingkang ngratoni godhong, kayu, banyu, pithik ingkang kangge uba rampe menika".

Maknanya untuk memperingati nabi Sulaiman yang menguasai dedaunan, kayu, air, ayam/semua hewan yang disembelih untuk 
perlengkapan. Daun maksudnya untuk membungkus atau alas nasi, kayu dan air maksudnya untuk memasak. Nilai ajaran budi pekerti yang terkandung ialah menumbuhkan cinta dan kasih sayang; memiliki tata krama dan sopan santun.

\section{Data 9}

"Dene sedaya uba rampe kangge mengeti dinten pitu pekenan gangsal sasi rolas windu wolu wuku tigangdoso bale lan griyo tanem tuwoh raja koyo jangkepipun dinten menika wilujeng ngajeng sak wingkingipun".

Maknanya, semua perlengkapan untuk memperingati tujuh hari (senin, selasa, rabu, kamis, jumat, sabtu, dan minggu), pasaran lima (pon, wage, kliwon, legi, pahing), satu tahun maksudnya dua belas bulan, satu windu maksudnya delapan tahun, jumlah wuku ada tiga puluh, pekarangan dan rumah yang ditempati, tanaman yang ditanam, hewan yang dipelihara, semua itu hari tersebut selamat dari sekarang sampai besok. Nilai ajaran budi pekerti yang terkandung ialah tumbuhnya disiplin diri; mengembangkan etos kerja dan belajar; memiliki rasa tanggung jawab.

\section{SIMPULAN}

Berdasarkan hasil dan pembahasan dapat diketahui simpulan dalam penelitian ini adalah sebagai berikut:

1. Makna mantra yang terkandung dalam tradisi Maguti ialah siraman pertama/tanggal satu cahaya wajah anak belum begitu bercahaya, sampai akhirnya tanggal limabelas bercahaya seperti bulan purnama; memperingati berasalnya dari bapak (putih) ibu (merah) atau air dan ari-ari sukma yang menjaga jiwa dan raganya anak yang dipaguti; memperingati saudara tua, orang yang melahirkan pertama itu mengeluarkan air dan daging yang menempel pada pusar; memperingati nabi dan rasul, istri dan anaknya, serta sahabatnya Usman, Umar, Syaidina, Ngali; memperingati ibu Dewi Fatimah yang menjadi contoh semua perempuan; memperingati leluhur perempuan laki-laki yang bertempat di kiblat empat lima pancer; memperingati para leluhur laki-laki perempuan, tua-muda, jauh-dekat dimintai doa restu yang baik; memperingati nabi Sulaiman yang menguasai dedaunan, kayu, air, ayam/semua hewan yang disembelih untuk perlengkapan; semua perlengkapan untuk memperingati tujuh hari.
2. Nilai ajaran budi pekerti yang terkandung adalah tumbuhnya disiplin diri; mampu berpikir positif; menumbuhkan cinta dan kasih sayang, rasa saling menghormati, memiliki tata krama dan sopan santun; menaati ajaran agama dan mengembangkan sikap toleransi; memiliki rasa tanggung jawab; rasa bakti kepada orang tua; mengembangkan etos kerja dan belajar.

\section{REFERENSI}

Herusatoto, B. 2001. Simbolisme dalam Budaya Jawa. Yogyakarta: PT Hanindita Graha Widia.

Widodo, D.I. 2014. Ngawi Tempo Doeloe. Surabaya: Dukut Publishing.

Sutardjo, I. 2012. Kajian Budaya Jawa. Surakarta: FSSR UNS.

Setiawan, K.E.P. 2019. Maguti: Simbolisme Budaya Jawa. Cirebon: Eduvision.

Singarimbun, M. 1982. Metode Penelitian Survey. Jakarta:LP3ES.

Koentjoroningrat.1984. Kebudayaan Jawa. Jakarta: Balai Pustaka.

Ronald, A. 1993. Transformasi Nilai-nilai Mistik dan Simbolik dalam Arsitektur Rumah Tradisional Jawa. Yogyakarta: Lembaga Javanologi Panunggalan.

\section{REFERENSI HASIL WAWANCARA}

Terima Kasih Kepada Narasumber:

Karno Sorok-Mbah, Dsn. Gedangan, Ds. Jagir RT.15 RW.01, Kec. Sine, Kab. Ngawi.

Martomakno-Mbah, Dsn. Plembeku, Ds. Jagir RT.13 RW.01, Kec. Sine, Kab. Ngawi.

Maryono-Bapak, Dsn. Tulakan Kulon, Desa Tulakan RT. 3 RW. 9, Kec. Sine, Kab. Ngawi.

Suparno-Ki Dalang, Dsn. Tulakan Kulon, Desa Tulakan RT. 3 RW. 9, Kec. Sine, Kab. Ngawi.

Paimin-Bapak, Dsn. Gedangan, Ds. Jagir RT.15 RW.01, Kec. Sine, Kab. Ngawi. 
Volume 4 No. 2 METALINGUA

Oktober 2019 Jurnal Pendidikan Bahasa dan Sastra Indonesia 